\title{
Bibliography of Works Cited
}

Abegg, Martin G., Jr. "The Linguistic Analysis of the Dead Sea Scrolls: More than (Initially) Meets the Eye." In Rediscovering the Dead Sea Scrolls. Edited by Maxine Grosssman, 48-68. Grand Rapids, MI: Eerdmans, 2010.

Abegg, Martin G., Jr., Peter Flint, and Eugene Ulrich. The Dead Sea Scrolls Bible: The Oldest Known Bible for the First Time in English. San Francisco: Harper, 1999.

Amit, Yairah. In Praise of Editing in the Hebrew Bible: Collected Essays in Retrospect. Sheffield: Sheffield Phoenix Press, 2012.

Andrews, Stephen. "What's the Matter with Eve? The Woman and her Sentence in Ancient Judaism." In Divine Creation in Ancient, Medieval, and Early Modern Thought; Essays Presented to the Rev'd Dr Robert D. Crouse. Edited by Michael Treschow, Willemien Otten, and Walter Hannam, 1-22. Leiden: Brill, 2007.

Archer, Léonie J. Her Price Is Beyond Rubies: The Jewish Woman in Graeco-Roman Palestine. Sheffield: Journal for Studies of the Old Testament (Jsот) Press, Supplement Series 6o, 1990.

Ashley, Timothy R. The Book of Numbers. Grand Rapids, MI: Eerdmans, 1993.

Baer, Yitzhak Fritz. Yisra'el Ba-Amim. Jerusalem: Bialik, 1955.

Baillet, Maurice. 4.III (4Q482-4Q520) DJD VII. Oxford: Clarendon, 1982.

Bal, Mieke. "Sexuality, Sin and Sorrow: The Emergence of the Female Character (a Reading of Genesis 1-3)." Poetics Today 6(1-2) (1985): 21-42.

Bandstra, Barry. Genesis 1-11: A Handbook on the Hebrew Text. Waco, Tx: Baylor University Press, 2008.

Bar-Tuviah, The Book of the Nazirites [Hebrew]. Warsaw: Publisher Safruth, 1910.

Baskin, Judith R. Midrashic Women: Formations of the Feminine in Rabbinic Literature. Hanover: Brandeis University Press, 2002.

"Rabbinic Judaism and the Creation of Woman." In Judaism Since Gender. Edited by Miriam Peskowitz and Laura Levitt, 125-130. New York: Routledge, 1997.

Bauckham, Richard J. "The Early Jerusalem Church, Qumran and the Essenes.” In The Dead Sea Scrolls as Background to Postbiblical Judaism and Early Christianity (papers from an International Conference at St. Andrews in 2001) 63-89. Leiden: Brill, 2003. Baumgarten, Joseph M. “4Q502: Marriage or Golden Age Ritual." Journal of Jewish Studies 34 (1983): 125-35.

. "On the Testimony of Women in 1QSa." Journal of Biblical Literature 76 (1957): 266-69.

. "Purification after Childbirth and the Sacred Garden in 4Q265 and Jubilees." In

New Qumran Texts and Studies, Proceedings of the First Meeting of the International Organization for Qumran Studies, Paris 1992. Edited by George J. Brooke with Florentíno García Martínez; Leiden: Brill, 1994. 
- "Scripture and Law in 4Q265." In Biblical Perspectives: Early Use and Interpretation of the Bible in Light of the Dead Sea Scrolls: Proceedings of the First International Symposium of the Orion Center for the Study of the Dead Sea Scrolls and Associated Literature, 12-14 May 1996. Edited by Michael E. Stone and Esther G. Chazon, 25-33. Leiden: Brill, 1998.

- The Damascus Document (4Q266-273), Qumran Cave IV (DJD XVIII). Oxford: Clarendon Press, 1996.

Be'er, Ilana. "Blood Discharge: On Female Im/Purity in the Priestly Code and in Biblical Literature." In A Feminist Companion to Exodus and Deuteronomy. Edited by Athalya Brenner, 152-64. Sheffield: Sheffield Academic Press, 1994.

Bechtel, Lyn M. "Rethinking the Interpretation of Genesis 2.4b-3.25." In Genesis: The Feminist Companion to the Bible (Second Series). Edited by Athalya Brenner, 77-117. Sheffield: Sheffield Academic Press, 1998.

Becking, Bob. Ezra, Nehemiah, and the Construction of Early Jewish Identity. Tübingen: Mohr Siebeck, 2011.

Berman, Saul J. "The Status of Women in Halakhic Judaism." Tradition 14(2) (1973): $5^{-28 .}$

Berthelot, Katell. "La Notion de גר גans les Texts de Qumrân." Revue de Qumran 19(2) (2000): 171-216.

Biale, Rachel. Women and Jewish Law: An Exploration of Women's Issues in Halakhic Sources. New York: Schocken Books, 1984.

Bird, Phyllis. "Images of Women in the Old Testament." In Religion and Sexism. Edited by Rosemary Redford Ruether, 41-88. New York: Simon and Schuster, 1974.

Blackstone, William. Commentaries on the Laws of England. I. Of the Rights of Persons (1765). Chicago: University of Chicago Press, 1979.

Blenkinsopp, Joseph. Creation, Un-Creation, Re-Creation: A Discursive Commentary on Genesis 1-11. London: T \& T Clark International, 2011.

_. Ezra/Nehemiah: A Commentary. Philadelphia: Westminster Press, 1988.

- Wisdom and Law in the Old Testament: The Ordering of Life in Israel and Early Judaism. Oxford: Oxford University Press, 1995.

Boecker, Hans Jochen. Law and the Administration of Justice in the Old Testament and Ancient East. Translated by Jeremy Moiser. Minneapolis, Mn: Augsburg Publishing House, 1980.

Boyarin, Daniel. Carnal Israel: Reading Sex in Talmudic Culture. Berkeley, CA: University of California Press, 1993.

Brettler, Marc Zvi. "Women and Psalms: Toward an Understanding of the Role of Women's Prayer in the Israelite Cult." In Gender and Law in the Hebrew Bible and the Ancient Near East. Edited by Bernard M. Levinson, Victor H. Matthews, and Tikva Frymer-Kensky, 25-56. Sheffield: Sheffield Academic Press, 1998. 
Brin, Gershon. "Divorce at Qumran." In Legal Texts and Legal Issues: Proceedings of the Second Meeting of the International Organization for Qumran Studies, Published in Honour of Joseph M. Baumgarten, Cambridge, 1995. Edited by Moshe Bernstein, Florentino García Martínez, and John Kampen, 231-44. Leiden: Brill, 1997.

—. "Reading in 4Q524 Frs. 15-22 DJD XXV." Revue de Qumran 74 (1999): 265-71.

Brodie, Thomas L. Genesis as Dialogue: A Literary, Historical, and Theological Commentary. Oxford: Oxford University Press, 2001.

Bronner, Leila Leah. From Eve to Esther: Rabbinic Reconstructions of Biblical Women. Louisville, KY: Westminster John Knox Press, 1994.

Brooke, George J. "Between Qumran and Corinth: Embroidered Allusions to Women's Authority." In The Dead Sea Scrolls as Background to Postbiblical Judaism and Early Christianity: Papers from an International Conference at St. Andrews in 2001. Edited by James R. Davila, 157-76. Leiden: Brill, 2001.

Brueggemann, Walter. "Of the Same Flesh and Bone (Gen 2.23a)." Catholic Biblical Quarterly 32 (1970): 532-542.

Cansdale, Lena. "Women Members of the Yahad according to the Qumran Scroll." Proceedings of the Eleventh World Congress of Jewish Studies, A (1993): 215-222.

Cansdale, Lena. Qumran and the Essenes: A Re-Evaluation of the Evidences. Tübingen: J.C.B. Mohr, 1997.

Cassuto, Umberto. A Commentary on the Book of Exodus (8th Edition) [Hebrew]. Jerusalem: Magness Press, 1987.

- A Commentary on the Book of Genesis. Translated by Israel Abrahams. Jerusalem: Magness Press, 1961.

Charles, R.H., trans. The Apocrypha and Pseudepigrapha of the Old Testament. Oxford: Clarendon Press, 1913.

Charlesworth, James H., ed., with F.M. Cross et al. The Dead Sea Scrolls: Hebrew, Aramaic, and Greek Texts with English Translations. Tübingen: J.C.B. Mohr, 1994.

Chepey, Stuart. Nazirites in Late Second Temple Judaism: A Survey of Ancient Writings, the New Testament, Archeological Evidence, and Other Writings from Late Antiquity. Leiden: Brill, 2005.

Clanton, Dan W., Jr. Daring, Disreputable and Devout; Interpreting the Bible's Women in the Arts and Music. New York: T \& T Clark International, 2009.

Coblenz Bautch, Kelly. "Amplified Roles, Idealized Depiction: Women in the Book of Jubilees." In Enoch and the Mosaic Torah: The Evidence of Jubilees. Edited by Gabriele Boccaccini and Giovanni Ibba, 338-52. Grand Rapids, MI: Eerdmans, 2009.

Cohen, Shaye J.D. “Are Women in the Covenant?" In A Feminist Commentary on the Babylonian Talmud: Introduction and Studies. Edited by Tal Ilan, Tamara Or, Dorothea M. Salzer, Christiane Steuer, and Irina Wandrey, 25-42. Tübingen: Mohr Siebeck, 2007. 
- "Conversion to Judaism in Historical Perspective: From Biblical Israel to Postbiblical Judaism." Conservative Judaism, 36(4) (1983): 31-45.

- "From the Bible to the Talmud: The Prohibition of Intermarriage." Hebrew Annual Review 7 (1983): 23-39.

—. "Solomon and the Daughter of Pharaoh: Intermarriage, Conversion, and the Impurity of Women." Journal of the Ancient Near Eastern Society of Columbia University (JANESCU) 16-17 (1987): 23-37.

—. The Beginnings of Jewishness: Boundaries, Varieties, Uncertainties. Berkeley, CA: University of California Press, 1999.

Cohn Eskenazi, Tamara. "Out from the Shadows: Biblical Women in the Postexilic Era." Journal for Studies of the Old Testament 54 (1992): 25-43.

Collins, John J. Beyond the Qumran Community: The Sectarian Movement of the Dead Sea Scrolls. Grand Rapids, MI: Eerdmans, 2010.

- "Forms of Community in the Dead Sea Scrolls." In Emanuel: Studies in Hebrew Bible, Septuagint and Dead Sea Scrolls in Honor of Emanuel Tov. Edited by Shalom M. Paul, Robert A. Kraft, Eva Ben-David, Lawrence H. Schiffman, and Weston W. Fields, 97-111. Leiden: Brill, 2002.

- Genesis 1-4: A Linguistic, Literary, and Theological Commentary. Phillipsburg, NJ: P \& R Publishing, 2006.

Conczorowski, Benedikt J. "All the same as Ezra?: Conceptual Differences between the Texts of Intermarriage in Genesis, Deuteronomy 7, and Ezra." In Mixed Marriages: Intermarriage and Group Identity in the Second Temple Period. Edited by Christian Frevel, 89-108. New York: T \& T Clark International, 2011.

Cotton, Hannah M. “The Rabbis and the Documents." InJews in a Graeco-Roman World. Edited by Martin Goodman; Oxford: Clarendon Press, 1998.

Cross, Frank Moore. The Ancient Library of Qumran (3rd revised and extended Edition). Sheffield: Sheffield Academic Press, 1995.

Cross, Frank Moore, and Esther Eshel. DJD Qumran Cave 4 XXXVI. Oxford: Clarendon Press 2000.

Davies, Philip R. Behind the Essenes: History and Ideology in the Dead Sea Scrolls. Atlanta, GA: Scholars Press, 1987.

—. "The birthplace of the Essenes: where is 'Damascus'?" Revue de Qumran 14(4) (1990): 503-519.

Davies, Philip R., and Joan E. Taylor, "On the Testimony of Women in 1QSa." Dead Sea Discoveries 3 (1996): 223-35.

de Hemmer Gudme, Anne Katrine. "How Should We Read Hebrew Bible Ritual Texts? A Ritualistic Reading of the Law of the Nazirite (Num 6:1-21)." Scandinavian Journal of the Old Testament 23(1) (2009): 64-84.

Delaney, Carol. "Abraham and the Seeds of Patriarchy." In Genesis: The Feminist Companion to the Bible (Second Series). Edited by Athalya Brenner, 129-149. Sheffield: Sheffield Academic Press, 1998. 
Diamond, Eliezer. "An Israelite Self-Offering in the Priestly Code: A New Perspective on the Nazirite." Jewish Quarterly Review 88, 1-2 (1997): 1-18.

- Holy Men and Hunger Artists: Fasting and Asceticism in Rabbinic Culture. Oxford: Oxford University Press, 2004.

Doering, Lutz. "Marriage and Creation in Mark 10 and CD 4-5." In Echoes from the Caves: Qumran and the New Testament. Edited by Florentíno García Martínez, 133-63. Leiden: Brill, 2009.

Douglas, Mary. Purity and Danger: An Analysis of the Concepts of Pollution and Taboo. London: Ark Paperbacks, 1988; 1st Edition, 1966.

Dupont-Sommer, A. The Essene Writings from Qumran. Cleveland, он: World Publishing, 1962.

Eco, Umberto. The Limits of Interpretation. Bloomington, IN: Indiana University Press, 1990.

Elbogen, Ismar. Prayer in Israel in Its Historical Development. Translated by Joshua Amir. Tel Aviv: Dvir Co., 1972.

Eliade, Mircea. Encyclopedia of Religion. New York: MacMillan Publishing Co., 1987.

Eliyahu, Aderet. The Book of the Precepts of the Jewish Karaites [Hebrew]. Jerusalem: The Association of the Jewish Karaites of Israel, 1966.

Elliger, Karl. Leviticus [German]. Tübingen: J.C.B. Mohr (Paul Siebeck), 1966.

Elwolde, John F. "Rwqmh in the Damscus Document and Ps 139:15." In Diggers at the Well: Proceedings of the Third International Symposium on the Hebrew of the Dead Sea Scroll and Ben Sira. Edited by Takamitsu Muraoka and John F. Elwolde, 65-83. Leiden: Brill, 2000.

Epstein, Louis. Marriage Laws in the Bible and Talmud. Cambridge, MA: Harvard University Press, 1942.

Evans Grubbs, Judith. Women and the Law in the Roman Empire: A Sourcebook on Marriage, Divorce and Widowhood. London: Routledge, 2002.

Fensham, F. Charles. The Books of Ezra and Nehemiah. Grand Rapids, MI: Eerdmans, 1982.

Fishbane, Michael A. "Accusation of Adultery: A Study of Law and Scribal Practice in Numbers 5:11-31." Hebrew Union College Annual 45 (1974): 25-45.

_ . "Interpretation of Mikra at Qumran." In Mikra: Text, Translation, Reading, and Interpretation of the Hebrew Bible in Ancient Judaism and Early Christianity. Edited by Martin Jan Mulder, 339-77. Assen/Maastricht: Van Gorcum, 1988.

Fraade, Steven D. "Ascetical Aspects of Ancient Judaism." In Jewish Spirituality from the Bible through the Middle Ages. Edited by Arthur Green, 252-88. New York: Crossroads, 1986.

- Legal Fictions; Studies of Law and Narrative in the Discursive Worlds of Ancient Jewish Sectarians and Sages. Leiden: Brill, 2011.

Franxman, Thomas W. Genesis and the "Jewish antiquities" of Flavius Josephus. Rome: Biblical Institute Press, 1979. 
Frevel, Christian, and Benedikt J. Conczorowski. "Deepening the Water: First Steps to a

Diachronic Approach on Intermarriage in the Hebrew Bible." In Mixed Marriages: Intermarriage and Group Identity in the Second Temple Period. Edited by Christian Frevel, 15-45. New York: T \& T Clark International, 2011.

Friedman, Shamma. "Sorting Out the Wages of Adultery: Execution, Ordeal or Divorce." In Shoshanat Yaakov:Jewish and Iranian Studies in Honor of Yaakov Elman. Edited by Shai Secunda and Steven Fine, 77-109. Leiden: Brill, 2012.

Friedman, Theodore. "The Shifting Role of Women, From the Bible to Talmud." Judaism, 36(4) (1987): 479-87.

Fröhlich, Ida. "Mamzer in Qumran Texts— the Problem of Mixed Marriages from Ezra's

Time. Law, Literature and Practice." Transeuphratène (2005): 103-115.

Frymer-Kensky, Tikva. In the Wake of the Goddesses: Women, Culture and the Biblical Transformation of Pagan Myth. New York: Ballantine, 1992.

_. "The Bible and Women's Studies." In Feminist Perspectives on Jewish Studies.

Edited by Lynn Davidman and Shelly Tenenbaum, 16-39. Ann Arbor, MI: Yale University Press, 1994.

—. "The Strange Case of the Suspected Sotah (Numbers V 11-31)." Vetus Testamentum 34 (1984): 11-26.

. "Virginity in the Bible." In Gender and Law in the Hebrew Bible and the Ancient

Near East. Edited by Bernard M. Levinson, Victor H. Matthews, and Tikva FrymerKensky, 79-96. Sheffield: Sheffield Academic Press, 1998.

García Martínez, Florentino. "Invented Memory: The 'Other' in the Dead Sea Scrolls." In Qumranica Minora II, Thematic Studies on the Dead Sea Scrolls. Edited by Eibert J.C. Tigchelaar, 187-218. Leiden: Brill, 2007.

- Qumranica Minora II, Thematic Studies on the Dead Sea Scrolls. Edited by Eibert J.C. Tigchelaar. Leiden: Brill, 2007.

García Martínez, Florentino, and Eibert J.C. Tigchelaar, eds. The Dead Sea Scrolls Study Edition (2 Volumes). Leiden: Brill, 1999.

Gaius, The Institutes of Gaius Translated and edited by W.M. Gordon and O.F. Robinson. Ithaca, NY: Cornell University Press, 1988.

Gerleman, Gillis. Ruth, Das Hohelied. Neukirchen-Vluyn: Neukirchener Verlag des Erziehungsvereins, 1965 .

Ginsburskaya, Mila. "Leviticus in the Light of the Dead Sea Scrolls: Atonement and Purification from Sin." In The Dead Sea in Context; Integrating the Dead Sea Scrolls in the Study of Ancient Texts, Languages, and Cultures. Edited by Armin Lange, Emmanuel Tov, Matthias Weigold, and Bennie H. Reynolds III, 263-277. Leiden: Brill, 2011.

Ginzberg, Louis. An Unknown Jewish Sect. New York: Jewish Theological Seminary of America, 1976.

Goldstein, Elyse. The Women's Torah Commentary: New Insights from Women Rabbis on the 54 Weekly Torah Portions. Woodstock, vT: Jewish Lights Publishing, 2000. 
Goodman, Martin. State and Society in Roman Galilee, A.D. 132-212. Totowa, NJ: Rowman \& Allanheld, 1983 .

Gordon, Leonard D. “Toward a Gender-Inclusive Account of Halakhah.” In Gender and Judaism: The Transformation of Tradition. Edited by T.M. Rudavsky, 3-12. New York: New York University Press, 1995.

Grabbe, Lester L. Ezra-Nehemiah. London and New York: Routledge, 1998.

Greidanus, Sydney. Preaching Christ from Genesis. Grand Rapids, MI: Eerdmans, 2007.

Grossman, Avraham. He Should Rule over You? Medieval Jewish Sages on Women [Hebrew]. Jerusalem: Zalman Shazar Center for Jewish History, 2011.

Grossman, Maxine L. "Reading for Gender in the Damascus Document." Dead Sea Discoveries 11 (2004): 212-39.

- Reading for History in the Damascus Document: A Methodological Study. Atlanta, GA: Society of Biblical Literature, 2009.

_ . "Rethinking of Gender in the Community Rule: An Experiment in Sociology." In The Dead Sea Scrolls and Contemporary Culture: Proceedings of the International Conference Held at the Israel Museum, Jerusalem (July 6-8, 2008). Edited by Adolfo D. Roitman, Lawrence H. Schiffman, and Shani Tzoref, 497-512. Leiden: Brill, 2011. "Women and Men in the Rule of the Congregation: A Feminist Critical Assessment." In Rediscovering the Dead Sea Scrolls: An Assessment of Old and New Approaches and Methods. Edited by Maxine L. Grossman, 229-45. Grand Rapids, MI: Eerdmans, 2010.

Gruber, Mayer I. "Women in the Religious System of Qumran." In Judaism in Late Antiquity. Edited by Alan J. Avery-Peck, Jacob Neusner, and Bruce Chilton, vol. 1, 173-96. Leiden: Brill, 2001.

Hacham, "Communal Fasts in the Judean Desert Scrolls," in Historical Perspectives: From the Hasmoneans to Bar Kokhba in Light of the Dead Sea Scrolls: Proceedings of the Fourth International Symposium of the Orion Center for the Study of the Dead Sea Scrolls and Associated Literature, 27-31 January, 1999 (ed. David Goodblatt, Avital Pinnick, and Daniel R. Schwartz; Leiden: Brill, 2000) 127-146.

Halpern Amaru, Betsy. "The First Woman, Wives, and Mothers in Jubilees." Journal of Biblical Literature 113/4 (1994): 6o9-626.

Hamilton, Victor P. The Book of Genesis Chapters 1-17. Grand Rapids, MI: Eerdmans, 1990.

Harrington, Hannah K. "Intermarriage in Qumran Texts:The Legacy of Ezra-Nehemiah.” In Mixed Marriages: Intermarriage and Group Identity in the Second Temple Period. Edited by Christian Frevel, 251-279. New York: T \& T Clark International, 2011.

_. "The Halakhah and Religion of Qumran." In Religion in the Dead Sea Scrolls. Edited by John J. Collins and Robert A. Kugler, 74-89. Grand Rapids, MI: Eerdmans, 2000.

Hartley, John E. New International Biblical Commentary: Genesis. Peabody, MA: Hendrickson, 2000. 
Hauptman, Judith. "Feminist Perspectives on Rabbinic Texts." In Feminist Perspectives on Jewish Studies. Edited by Lynn Davidman and Shelly Tenenbaum, 40-61. New Haven, ст: Yale University Press, 1994.

_. Rereading the Rabbis: A Woman's Voice. Boulder, Colorado: Westview Press, 1998. ."Women and Jewish Law." In Women andJudaism, New Insights and Scholarship. Edited by Frederick E. Greenspahn, 64-87. New York: New York University Press, 2009 .

Hayes, Christine E. Gentile Impurities and Jewish Identities: Intermarriage and Conversion from the Bible to the Talmud. Oxford: Oxford University Press, 2002.

—. "Intermarriage and Impurity in Ancient Jewish Sources." Harvard Theological Review 92(1) (1999): 3-36.

Heger, Paul. "Celibacy in Qumran-Hellenistic Fiction or Reality? Qumran's Attitude Toward Sex." Revue de Qumran 101(26) (2013): 53-90.

- Challenges to Conventional Opinions on Qumran and Enoch Issues (Studies on the Texts of the Desert of Judah 100). Leiden: Brill, 2011.

- Cult as the Catalyst for Division: Cult Disputes as the Motive for Schism in the Pre-7o Pluralistic Environment. Leiden: Brill, 2007.

—. “Did Prayer Replace Sacrifice at Qumran?” Revue de Qumran 22(2) (2005): $213-233$.

_ .Halakhic Disputes between Rabbis and Qumranic Authors." Estudios Bíblicos $69(3)(2011): 323-36$.

. "Patrilineal or Matrilineal Genealogy in Israel after Ezra." Journal for the Study of Judaism 43 (2012): 215-248.

- . "Qumranic Marriage Prohibitions and Rabbinic Equivalents." Revue de Qumran 95, 24(3) (May 2010): 441-451.

- "Source of Law in the Biblical and Mesopotamian Law Collection." Biblica Vol. 86, Fasc. 3 (2006): 324-342.

—. "Stringency in Qumran?" Journal for the Study of Judaism 42 (2011): 1-30.

—. "The Development of the Qumran Law-Nistarot, Niglot and the Issue of 'Contemporization.” Revue de Qumran 9o(23), 2 (2007): 167-206.

- The Pluralistic Halakhah: Legal Innovations in the Late Second Commonwealth and Rabbinic Periods. Berlin: De Gruyter, 2003.

- "Unabashedly Reading Desired Outcomes into Scripture." In Vixens Disturbing Vineyards: Embarrassment and Embracement of Scriptures; Festschrift in Honour of Harry Fox (leBeit Yoreh). Edited by Tzemah Yoreh, Miryam Segal, Aubrey Glazer, and Justin Lewis, 96-139. Boston: Academic Studies Press, 2010.

Heschel, Susannah. "The Religious Issue, Religion and Its Discontents." AJS Perspectives: The Magazine of the Association for Jewish Studies (Fall 2011): 6-7.

Himmelfarb, Martha. "Sexual Relations and Purity in the Temple Scroll and the Book of Jubilees." Dead Sea Discoveries 6(1) (1999): 11-36. 
Hoffmann, David Z. Das Buch Leviticus. Hebrew translation by Zvi HarShefer and Ahron Lieberman. Jerusalem: Mossad Harav Kook, 1953.

Holmén, Tom. "Divorce in CD 4:20-5:2 and 11QT 57:17-18: Some remarks on the Pertinence of the Question." Revue de Qumran 18 (1998): 397-408.

Holtz, Gudrun. "Inclusivism at Qumran." Dead Sea Discoveries 16(1) (2009): 22-54.

Houtman, Cornelis. Das Bundesbuch, Ein Kommentar. Leiden: Brill, 1997.

Hurowitz, Victor. "המקור in the Damascus Document 4QDe (4Q270) 7i:14." Dead Sea Discoveries 9 (2002): 34-37.

Ilan, Tal. Jewish Women in Greco-Roman Palestine: An Inquiry into Image and Status. Tübingen: J.C.B. Mohr (Paul Siebeck), 1995.

_. "Reading for Women in 1QSa (Serekh Ha-edah)." In The Dead Sea Scrolls in Context: Integrating the Dead Sea Scrolls in the Studies of Ancient Texts, Languages and Cultures. Edited by Armin Lange, Emmanuel Tov, Matthias Weigold, and Bennie H. Reynolds III, 61-76. Leiden: Brill, 2011.

- "The Attraction of Aristocratic Women to Pharisaism During the Second Temple Period." Harvard Theological Review 88 (1995): 1-33.

_. "Women in Jewish Life and Law." In The Cambridge History of Judaism, Vol. 4. Edited by W.D. Davies and Louis Finkelstein, 627-46. Cambridge: Cambridge University Press, 2006.

—_. "Women in Qumran and the Dead Sea Scrolls." In The Oxford Handbook of the

Dead Sea Scrolls. Edited by Timothy H. Lim and John J. Collins, 123-147. Oxford:

Oxford University Press, 2010.

Instone-Brewer, David. "Deuteronomy 24:1-4 and the Origin of the Jewish Divorce Certificate." Journal of Jewish Studies 59(2) (1998): 230-243.

- Divorce and Remarriage in the Bible, The Social and Literary Context. Grand Rapids, MI: Eerdmans, 2002.

—. "Jewish Women Divorcing Their Husbands in Early Judaism: The Background to Papyrus Se'elim 13." Harvard Theological Review 92(3) (1999): 349-57.

Jackson, Bernard S. "Liability of Mere Intention in Early Jewish Law." Hebrew Union College Annual 42 (1971): 197-225.

Jacob, Benno. The Second Book of the Bible: Exodus. Translated with an introduction by Walter Jacob in association with Yaakov Elman. Hoboken, NJ: Ktav Publishing House, 1992.

Japhet, Sara. "The expulsion of the foreign women (Ezra 9-10): The legal basis, and consequences for the definition of Jewish identity." In Sieben Augen auf einem Stein (Sach 3,9)-Studien zur Literatur des Zweiten Tempels; Festschrift für Ina Willi-Plein zum 65. Geburtstag. Edited by Friedhelm Hartenstein and Michael Pietsch, 141-161. Neukirchen-Vluyn: Neukirchener Verlag, 2007.

- The Ideology of the Book of Chronicles and its Place in Biblical Thought. Translated from the Hebrew by Anna Barber. Winona Lake, IN: Eerdmans, 2009. 
Jastrow, Marcus. A Dictionary of the Targumim, the Talmud Babli and Yerushalmi and the Midrashic Literature. Leipzig, 1903; Jerusalem: Horeb, n.d.

Joas, Hans. Die Zehn Gebote, Ein widersprüchliches Erbe? Cologne: Böhlau Verlag, 2006. Johnson, Willa M. The Holy Seed has been Defiled: The Interethnic Marriage Dilemma in Ezra 9-10. Sheffield: Sheffield Phoenix Press, 2011.

Kahane, Avraham. The Apocryphal Books [Hebrew]. Tel Aviv: Massada, 1959.

Kaiser, Otto. Isaiah 1-12: A Commentary. Translated by R.A. Wilson. Philadelphia: Westminster Press, 1972.

Kampen, John. "A Fresh Look at the Masculine Plural Suffix in CD IV:21." Revue de Qumran 16 (1993): 91-97.

"The Matthean Divorce Texts Reexamined." In New Qumran Texts and Studies: Proceedings of the First Meeting of the International Organization for Qumran Studies, Paris 1992. Edited by George J. Brooke with Florentino García Martínez, 149-67. Leiden: Brill, 1994.

Kessler, Gwynn. Conceiving Israel: The Fetus in Rabbinic Narrative. Philadelphia: University of Pennsylvania Press, 2009.

Klawans, Jonathan. Impurity and Sin in Ancient Judaism. New York: Oxford University Press, 2000.

Klinghardt, Matthias. "The Manual of Discipline in the Light of Statutes of Hellenistic Associations." In Methods of Investigation of the Dead Sea Scrolls and the Khirbet Qumran Site. Present Realities and Future Prospects. Edited by Michael O. Wise, Dennis G. Pardee, John J. Collins, and Norman Golb, 251-70. Annals of the New York Academy of Sciences 722. New York: The New York Academy of Sciences, 1994.

Koltun-Fromm, Naomi. Hermeneutics of Holiness: Ancient Jewish and Christian Notions of Sexuality and Religious Community. New York: Oxford University Press, 2010.

Kraemer, Ross Shepard. "Jewish Women in the Diaspora World of Late Antiquity." In Jewish Women in Historical Perspective (2nd Edition). Edited by Judith R. Baskin, 46-72. Detroit, MI: Wayne State University Press, 1998.

- Her Share of the Blessings: Women's Religions among Pagans, Jews, and Christians in the Greco-Roman World. New York: Oxford University Press, 1992.

Kriger, Diane. Sex Rewarded, Sex Punished: A Study of the Status "Female Slave" in Early Jewish Law. Boston: Academic Studies Press, 2011.

Kugel, James. "The Holiness of Israel and the Land in Second Temple Times." In Texts, Temples, and Traditions: A Tribute to Menahem Haran. Edited by Michael V. Fox, Victor Avigdor Hurowitz, Avi Hurvitz, Michael L. Klein, Baruch J. Schwartz, and Nili Shupak, 21-32. Winona Lake, IN: Eisenbrauns, 1996.

Kugler, Robert A. "Hearing 4Q225: A Case Study in Reconstructing the Religious Imagination of the Qumran Community." Dead Sea Discoveries 10(1) (2003): 81-103.

_. "Making All Experience Religious: The Hegemony of Ritual at Qumran." Journal for the Study of Judaism 33(2) (2001): 131-52. 
Kvam, Kristen E., Linda S. Schearing, and Valarie H. Ziegler. Eve and Adam: Jewish, Christian, and Muslim Readings on Genesis and Gender. Bloomington, IN: Indiana University Press, 1999.

Lacheman, Ernest R. “Note on Ruth iv 7-8." Journal of Biblical Literature 56 (1937):53-6. Lacks, Roslyn. Women and Judaism: Myth, History, and Struggle. New York: Doubleday, 1980.

Lambert, David. "Fasting as a Penitential Rite: A Biblical Phenomenon." Harvard Theological Review 96(4) (2003): 477-512.

Lange, Armin. "Mixed Marriages and the Hellenistic Religious Reforms." In Mixed Marriages: Intermarriage and Group Identity in the Second Temple Period. Edited by Christian Frevel, 205-219. New York: T \& T Clark International, 2011.

Lapsley, J.E. "The Voice of Rachel: Resistance and Polyphony in Genesis 31:14-35." In Genesis: The Feminist Companion to the Bible (Second Series). Edited by Athalya Brenner, 233-48. Sheffield: Sheffield Academic Press, 1998.

Lawrence, Louise. "Men of Perfect Holiness (1QS 7.20): Social-Scientific Thoughts on Group Identity, Asceticism and Ethical Development in the Rule of the Community." In New Directions in Qumran Studies: Proceedings of the Bristol; Colloquium on the Dead Sea Scroll, 8-10 September 2003. Edited by Jonathan G. Campbell, William John Lyons, and Lloyd Keith Pietersen, 83-100. London: T \& T Clark International, 2005. Lefkovitz, Lori. In Scripture: The First Stories of Jewish Sexual Identities. Lanham, MD: Rowman \& Littlefield Publishers, 2010.

Levine, B.A. "In Praise of the Israelite Mishpaha: Legal Themes in the Book of Ruth" in The Quest for the Kingdom of God: Studies in Honor of G. E. Mendehall. Edited by H.B. Huffmon, Frank A. Spina, and Whitney Green, 95-106. Winona Lake, IN: Eisenbrauns, 1983.

Levinson, Bernard M. The Right Chorale: Studies in Biblical Law and Interpretation. Tübingen: Mohr Siebeck, 2008.

Licht, Jacob. The Rule Scroll: A Scroll from the Wilderness of Judaea (1QS $\left.1 Q S a{ }_{1} Q S b\right)$. Jerusalem: The Bialik Institute, 1965; reprinted 1996.

Loader, William. Philo, Josephus and the Testaments on Sexuality: Attitudes towards Sexuality in the Writings of Philo and Josephus and in the Testaments of the Twelve Patriarchs. Grand Rapids, MI: Eerdmans, 2011.

- The Dead Sea Scrolls on Sexuality: Attitudes towards Sexuality in Sectarian and Related Literature at Qumran. Grand Rapids, MI: Eerdmans, 2009.

Maccoby, Hyam. "Holiness and purity: the holy people in Leviticus and EzraNehemiah." In Reading Leviticus: a conversation with Mary Douglas. Edited by John F.A. Sawyer, 153-170. Sheffield: Sheffield Academic Press, 1996.

Maier, Johann. The Temple Scroll: An Introduction, Translation \& Commentary. Translated by Richard T. White; edited by David J.A. Clines and Philip R. Davies. Sheffield: University of Sheffield, 1985 . 
Maimonides, Moses. Introduction to Interpretation of the Mishna. Translated from Arabic to Hebrew by Joseph Kapach. Jerusalem: Mossad HaRav Kook, 1961; 8th reprint, 1993 .

- The Guide of the Perplexed. Translated by Shlomo Pines. Chicago: University of Chicago Press, 1963.

Markl, Dominik. Der Dekalog als Verfassung des Gottesvolkes, Die Brennpunkte einer Rechtshermeneutik des Pentateuch in Exodus 19-24 und Deuteronomium 5. Freiburg: Herder, 2007.

Martin, Emily. The Woman in the Body: A Cultural Analysis of Reproduction. Boston: Beacon Press, 2001.

Matthews, Victor H. "Honor and Shame in Gender-Related Legal Situations in the Hebrew Bible." In Gender and Law in the Hebrew Bible and the Ancient Near East. Edited by Bernard M. Levinson, Victor H. Matthews, and Tikva Frymer-Kensky, 97-112. Sheffield: Sheffield Academic Press, 1998.

Meacham, Tirzah Z. "Mishna Tractate Niddah with Introduction. A Critical Edition with Notes on Variants, Comments, Redaction and Chapters in Legal History and Realia." Dissertation, The Hebrew University, Jerusalem, 1989.

Merrill Groothuis, Rebekah. Good News for Women: A Biblical Picture of Gender Equality. Grand Rapids, MI: Baker Books, 1997.

Metso, Sarianna. "Whom Does the Term Yahad Identify?" in Biblical Traditions in Transmission: Essays in Honour of Michael A. Knibb. Edited by Charlotte Hempel and Judith M. Lieu, 213-35. Leiden: Brill, 2006.

Meyers, Carol L. "Gender roles and Genesis 3:16 revisited." In The Word of the Lord Shall Go Forth: Essays in Honor of David Noel Freedman in Celebration of His Sixtieth Birthday. Edited by Carol L. Meyers and M. O'Connor, 337-354. Winona Lake, IN: Eisenbrauns, 1983 .

- Rediscovering Eve: Ancient Israelite Women in Context. Oxford: Oxford University Press, 1988.

Michel, Joanna L., G.B. Mahady, M. Veliz, and D.D. Soejarto. "Symptoms, Attitudes and Treatment Choices Surrounding Menopause among the Q'eqchi Maya of Livingston, Guatemala." Social Science and Medicine 63 (2006): 732-42.

Milgrom, Jacob. Numbers/במדבר: The Traditional Hebrew Text with the New JPS Translation. Philadelphia: Jewish Publication Society, 1990.

Murphy, Catherine M. Wealth in the Dead Sea Scrolls and in the Qumran Community. Leiden: Brill, 2002.

Neusner, Jacob. Aphrahat and Judaism: The Christian-Jewish Argument in FourthCentury Iran. Leiden: Brill, 1971.

- How the Rabbis Liberated Women. Atlanta, GA: Scholars Press, 1998. . Method and Meaning in Ancient Judaism. Missoula, мт: Scholars Press, 1979. 
Newsom, Carol A. "Models of the Moral Self: Hebrew Bible and Second Temple Judaism." JBL 131(1) (2012): 5-25.

Newsom, Carol A., and Sharon H. Ringe, eds., The Women's Bible Commentary. Louisville, KY: Westminster John Knox Press, 1998.

Nickelsburg, George W.E. 1 Enoch 1: A Commentary on the Book of 1 Enoch, Chapter 1-36: 81-108. Minneapolis, MN: Fortress Press, 2001.

Niditch, Susan. "Defining and Controlling Others Within: Hair, Identity, and the Nazirite Vow in a Second Temple Context." In The "Other" in Second Temple Judaism, Essays in Honour ofJohn J. Collins. Edited by Daniel C. Harlow, Marina Martin Hogan, Matthew Goff, and Joel S. Kaminsky, 67-85. Grand Rapids, M I: Eerdmans, 2011. . My Brother Esau is a Hairy Man: Hair and Identity in Ancient Israel. New York: Oxford, 2008.

_. "Portrayals of Women in the Hebrew Bible." In Jewish Women in Historical Perspective (2nd Edition). Edited by Judith R. Baskin, 25-45. Detroit, MI: Wayne State University Press, 1998.

"The Cosmic Adam: Man as Mediator in Rabbinic Literature." Journal for the Study of Judaism 34(2) (1983): 137-46.

Nitzan, Bilhah. Qumran Prayer and Poetry [Hebrew]. Jerusalem: Mossad Bialik, 1996.

Noam, Vered. "Divorce in Qumran in Light of Early Halakhah.” Journal of Jewish Studies LVI (2) (2005): 206-23.

—. "Stringency in Qumran: A Reassessment." Journal for the Study of Judaism 40 (2009): $342-55$.

Noort, Ed. "The Creation of Man and Woman in Biblical and Ancient Near Eastern Traditions." In The Creation of Man and Woman: Interpretation of the Biblical Narratives in Jewish and Christian Traditions. Edited by Gerard P. Luttikhuizen, 1-18. Leiden: Brill, 2000.

Noth, Martin. Leviticus: A Commentary. Translated by J.E. Anderson. London: SCM Press, 1965 .

Olyan, Saul M. Rites and Rank: Hierarchy in Biblical Representations of Cult. Princeton, NJ: Princeton University Press, 2000.

Otto, Eckart. "False Weights in the Scale of Biblical Justice? Different Views of Women from Patriarchal Hierarchy to Religious Equality in the Book of Deuteronomy." In Gender and Law in the Hebrew Bible and the Ancient Near East. Edited by Bernard M. Levinson, Victor H. Matthews, and Tikva Frymer-Kensky, 128-46. Sheffield: Sheffield Academic Press, 1998.

Pakkala, Juha. "Intermarriage and Group Identity in the Ezra Tradition (Ezra 7-10 and Nehemiah 8)." In Mixed Marriages: Intermarriage and Group Identity in the Second Temple Period. Edited by Christian Frevel, 78-88. New York: T \& T Clark International, 2011. 
Ezra the Scribe, The Development of Ezra 7-10 and Nehemiah 8, BZAW 347. Berlin: De Gruyter, 2004.

Paul, Shalom. Studies in the Book of the Covenant in the Light of Cuneiform and Biblical Law. Leiden: Brill, 1970.

Pietersma, Albert, and Benjamin G. Wright. A New English Translation of the Septuagint. New York: Oxford University Press, 2007.

Pressler, Carolyn. "Wives and Daughters, Bond and Free: Views of Women in the Slave Laws of Exodus 21.2-11." In Gender and Law in the Hebrew Bible and the Ancient Near East. Edited by Bernard M. Levinson, Victor H. Matthews, and Tikva Frymer-Kensky, 147-72. Sheffield: Sheffield Academic Press, 1998.

Qimron, Elisha. "Celibacy in the Dead Sea Scrolls and the Two Kinds of Sectarians." In

The Madrid Qumran Congress: Proceedings of the International Congress on the Dead Sea Scrolls, Madrid, 18-21 March 1991. Edited by Julio Trebolle Barrera and Luis Vegas Montaner, 287-94. Leiden: Brill, 1992.

Rabin, Chaim. The Zadokite Documents (Oxford: Clarendon, 1954).

Regev, Eyal. "Cherchez les femmes: Were the Yahad Celibates?" Dead Sea Discoveries 15 (2008): 253-84.

Rendtorff, Rolf. "The 'ger' in the priestly laws of the Pentateuch." In Ethnicity and the Bible. Edited by M.G. Brett, 77-87. Leiden: Brill, 1996.

Rofé, Alexander. Deuteronomy: Issues and Interpretation. London: T \& T Clark, 2002.

. "The Tenth Commandment in the Light of Four Deuteronomic Laws." In The Ten Commandments in History and Tradition. Edited by Ben-Zion Segal; English version edited by Gershon Levi, 45-65. Jerusalem: Magnes Press, 1990.

Romney Wegner, Judith. Chattel or Person? The Status of Women in the Mishnah. New York: Oxford University Press, 1988.

_ . "Philo's Portrayal of Women-Hebraic or Hellenic?" In Women Like This: New Perspectives on Jewish Women in the Greco-Roman World. Edited by Amy-Jill Levine, 41-66. Atlanta, GA: Scholars Press, 1991.

- The Status of Women in the Mishnah. New York: Oxford University Press, 1988.

- "Women in Classical Rabbinic Judaism." In Jewish Women in Historical Perspective (2nd Edition). Edited by Judith R. Baskin, 73-100. Detroit: Wayne State University Press, 1998.

Roth, Martha T. "Gender and Law: A Case Study from Ancient Mesopotamia." In Gender and Law in the Hebrew Bible and the Ancient Near East. Edited by Bernard M. Levinson, Victor H. Matthews, and Tikva Frymer-Kensky, 173-84. Sheffield: Sheffield Academic Press, 1998.

_. Law Collections from Mesopotamia and Asia Minor (Second Edition). Atlanta, GA: Scholars Press, 1997 .

Rothenbusch, Ralf. "The Question of Mixed Marriages between the Poles of Diaspora and Homeland: Observations in Ezra-Nehemiah." In Mixed Marriages:Intermarriage 
and Group Identity in the Second Temple Period. Edited by Christian Frevel, 6o-77. New York: T \& T Clark International, 2011.

Rothstein, David. "Women's Testimony at Qumran: The Biblical and Second Temple Evidence." Revue de Qumran 21 (2004): 597-614.

Sacks, Robert D. A Commentary on the Book of Genesis. Lewiston, NY: Edwin Mellen, 1990.

Safrai, Hannah. "Women and the Ancient Synagogue." In Daughters of the King: Women and the Synagogue: A Survey of History, Halakhah, and Contemporary Realities. Edited by Susan Grossman and Rivka Haut, 39-49. Philadelphia: Jewish Publication Society, 1992.

Safrai, Shmuel. "The Obligations of Women [to Perform] Precepts in the Teaching of Tannaim" [Hebrew]. Bar-Ilan: Annual of Bar-Ilan University, Studies in Judaica and the Humanities (1995): 227-36.

Sardenberg, Cecilia. "Of Bloodletting, Taboos and Powers: Menstruation from a Socioanthropological Perspective." Estudos Feministas 2. Portuguese, 1994.

Sarna, Nahum M., commentary to Genesis/בראשית: The Traditional Hebrew Text with the New JPS Translation. Philadelphia:Jewish Publication Society, 1989.

Sasson, Jack M. Ruth: A New Translation with a Philological Commentary and a FormalistFolklorist Interpretation. Baltimore, MD: Johns Hopkins University Press, 1979.

Sassoon, Isaac. The Status of Women in Jewish Tradition. New York: Cambridge University Press, 2011.

Satlow, Michael L. “4Q502e A New Year Festival?” Dead Sea Discoveries 5 (1998): 57-68. - Jewish Marriage in Antiquity. Princeton, NJ: Princeton University Press, 2001. . "Rhetoric and Assumptions: Romans and Rabbis on Sex." In Jews in a GraecoRoman World. Edited by Martin Goodman, 135-144. Oxford: Clarendon Press, 1998.

Schechter, Solomon, ed. Avoth de-Rabbi Nathan: Solomon Schechter Edition with references to parallel in the two versions and to the addenda in the Schechter edition with Foreword by Menahem Kister [Hebrew]. New York and Jerusalem:Jewish Theological Seminary of America (JTS) Press, 1997.

Schiffman, Lawrence H. "At the Crossroads: Tannaitic Perspectives on the JewishChristian Schism." In Jewish and Christian Self-Definition, Vol. 2: Aspects of Judaism in the Greco-Roman Period. Edited by E.P. Sanders, Albert I. Baumgarten, Alan Mendelson, 115-56. Philadelphia: Fortress Press, 1981.

_ .Laws Pertaining to Women in the Temple Scroll." In The Dead Sea Scrolls: Forty Years of Research. Edited by Devorah Dimant and Uriel Rappaport, 209-28. Leiden: Brill, 1992.

- Reclaiming the Dead Sea Scrolls: The History of Judaism, the Background of Christianity, the Lost Library of Qumran. Philadelphia: The Jewish Publication Society, 1994 . 
- Sectarian Law in the Dead Sea scrolls: Courts, Testimony, and the Penal Code. Atlanta, GA: Scholars Press, 1983.

- The Eschatological Community of the Dead Sea Scrolls: A Study of the Rule of the Congregation. Atlanta, GA: Scholars Press, 1989.

- "The Law of Vows and Oaths (Num 30, 3-16) in the Zadokite Fragments and the Temple Scroll." Revue de Qumran 57/8, 15 (1991): 199-214.

Schiffman, Lawrence H., ed. Encyclopedia of the Dead Sea Scrolls. New York: Oxford University Press, 2000.

Schmidt, Werner H. Die Schöpfungsgeschichte der Priesterschrift; Zur Überlieferungsgeschichte von Genesis 1, 1-1-2,4a und 2, 4b-3, 24. Neukirchen: Neukirchener Verlag, 1973. Scholz, Suzanne. “Through Whose Eyes? A 'Right' Reading of Genesis 34." In Genesis:

The Feminist Companion to the Bible (Second Series). Edited by Athalya Brenner, 150-71. Sheffield: Sheffield Academic Press, 1998.

Schremer, Adiel. "Qumran Polemic on Marital Law: CD 4:20-5:11 and Its Social Background." In The Damascus Document: A Centennial of Discovery; Proceedings of the Third International Symposium of the Orion Center for the Study of the Dead Sea Scrolls and Associated Literature, 4-8February 1998. Edited by Joseph M. Baumgarten, Esther G. Chazon, and Avital Pinnick, 147-6o. Leiden: Brill, 2000.

Schuller, Eileen. "Women in the Dead Sea Scrolls." In The Dead Sea Scrolls after 50 Years: A Comprehensive Assessment. Edited by Peter W. Flint and James C. VanderKam, Vol. 2, 117-144. Leiden: Brill, 1998.

"Women in the Dead Sea Scrolls: Some Observations from a Dictionary." Revue de Qumran 93 (2009): 49-59.

Schwartz, Daniel R. "On two Aspects of a Priestly View of Descent at Qumran." In Archeology and History in the Dead Sea Scrolls. Edited by Lawrence H. Schiffman, 157-179. Sheffield: Journal for Studies of the Old Testament (Jsot) Press, 1990.

—. "Yannai and Pella, Josephus and Circumcision." Dead Sea Discoveries 18/3 (2011): 339-359.

Segal, Michael. The Book of Jubilees: Rewritten Bible, Redaction, Ideology and Theology. Leiden: Brill, 2007.

Shemesh, Aharon. "4Q271.3: A Key to Sectarian Matrimonial Law." Journal of Jewish Studies 49(2) (1998): 244-263.

"Marriage and Marital Life in the Dead Sea Scrolls." In The Dead Sea Scrolls and Contemporary Culture: Proceedings of the International Conference Held at the Israel Museum, Jerusalem (July 6-8, 2008). Edited by Adolfo D. Roitman, Lawrence H. Schiffman, and Shani Tzoref, 589-6oo. Leiden: Brill, 2011.

_ . "Scriptural Interpretations in the Damascus Document and their Parallels in Rabbinic Midrash." In The Damascus Document: A Centennial of Discovery; Proceedings of the Third International Symposium of the Orion Center for the Study of the Dead Sea Scrolls and Associated Literature, 4-8 February 1998. Edited by Joseph M. Baumgarten, Esther G. Chazon, and Avital Pinnick, 161-75. Leiden: Brill, 2000. 
- "Women and Their Status in Society and Halakhah According to Qumran Literature." [Hebrew] Yearbook of Bar Ilan University 30/31 (2006): 533-46.

Simkins, Ronald A. "Gender Construction in the Yahwist Creation Myth." In Genesis: The Feminist Companion to the Bible (Second Series). Edited by Athalya Brenner, 32-51. Sheffield: Sheffield Academic Press, 1998.

Siquans, Agnethe. "Foreignness and Poverty in the Book of Ruth: A Legal Way for a Poor Foreign Woman to Be Integrated into Israel." Journal of Biblical Literature 128(3) (2009): 443-452.

Smith-Christopher, Daniel L. "The Mixed Marriage Crisis in Ezra 9-10 and Nehemiah 13: A Study of the Sociology of the Post-Exilic Judean Community." In Second Temple Studies 2. Edited by Tamara C. Eskenazi and Kent Richards, 243-265. Sheffield: Journal for Studies of the Old Testament (JSOT) Press, 1994.

Sokoloff, Michael. A Dictionary of Jewish Palestinian Aramaic. Jerusalem: Bar Ilan University, 1990.

Southwood, Katherine E. "An Ethnic Affair? Ezra's Intermarriage Crisis against a Context of 'Self Ascription' and 'Description of Others,' " in Mixed Marriages: Intermarriage and Group Identity in the Second Temple Period. Edited by Christian Frevel, 46-59. New York: T \& T Clark International, 2011.

- Ethnicity and the Mixed Marriage Crisis in Ezra 9-10: An Anthropological Approach. Oxford: Oxford University Press, 2012.

Stegemann, Hartmut. The Library of Qumran: On the Essenes, Qumran, John the Baptist, and Jesus. Grand Rapids, MI: Eerdmans, 1998.

—. "The Qumran Essenes." In The Madrid Qumran Congress: Proceedings of the International Congress on the Dead Sea Scrolls, Madrid, 18-21 March 1991. Edited by Julio Trebolle Barrera and Luis Vegas Montaner, vol. 1, 83-166. Leiden: Brill, 1992.

Stemberger, Günter. Das klassische Judentum: Kultur und Geschichte der rabbinischen Zeit (Revised Edition). Munich: Beck, 2009.

Steudel, Annette. "The Damascus Document (D) as a Rewriting of the Community Rule (S)." Revue de Qumran 100, 25, 4 (2012): 605-620.

Swidler, Leonard. Biblical Affirmations of Woman. Philadelphia: Westminster Press, 1979.

Talmon, S. The World of Qumran from Within. Leiden: Brill, 1989.

Tertullian. De Cultu Feminarum, The Fathers of the Church. Dokkum: J. Kaminga, 1934. Teugels, L. "The Creation of the Human in Rabbinic Interpretation." In The Creation of Man and Woman: Interpretation of the Biblical Narratives in Jewish and Christian Traditions. Edited by Gerard P. Luttikhuizen, 107-27. Leiden: Brill, 2000.

Thackeray, H. St. J., trans. Josephus (Loeb Classical Library). Cambridge, MA: Harvard University Press, 1926.

Thompson, Thomas and Dorothy. "Some Legal Problems in the Book of Ruth." Vetus Testamentum 18, 79-99. Leiden: Brill, 1968.

Tov, Emanual, ed. The Dead Sea Scrolls Electronic Library (DSSEL). Leiden: Brill, 2006. 
Trible, Phyllis. God and the Rhetoric of Sexuality. Philadelphia: Fortress Press, 1978.

Urbach, Ephraim E. The World of the Sages: Collected Studies [Hebrew]. Jerusalem: Magness Press, 2002.

van Houten, Christiana. The Alien in Israelite Law. Sheffield: Sheffield Academic Press, 1991.

van Ruiten, J.T.A.G.M. Primeval History Interpreted: The Rewriting of Genesis 1-11 in the Book of Jubilees. Brill: Leiden, 2000.

_ . "The Creation of Man and Woman in Early Jewish Literature." In The Creation of Man and Woman: Interpretation of the Biblical Narratives in Jewish and Christian Traditions. Edited by Gerard P. Luttikhuizen, 34-62. Leiden: Brill, 2000.

Veijola, Timo. Moses Erben: Studien zum Dekalog, zum Deuteronomismus und zum Schriftgelehrtum. Stuttgart: W. Kohlhammer, 2000.

Vermes, Géza. “Sectarian Matrimonial Halakhah in the Damascus Rule." Journal of Jewish Studies 25 (1974): 197-202.

Vermes, Géza, trans. The Dead Sea Scrolls in English (3rd Edition). London: Penguin, 1987.

Viberg, Åke. Symbols of Law: A Contextual Analysis of Legal Symbolic Acts in the Old Testament. Stockholm: Almquist \& Wiksell, 1992.

von Rad, Gerhard. Genesis: A Commentary (Revised Edition). Translated from the German by John H. Marks. Philadelphia: Westminster Press, 1972.

Waller, Shulamit. Women and Womanhood in the Talmudic Narratives [Hebrew]. Tel Aviv: Hakibbutz Hameuchad, 1993.

Wassen, Cecilia. Women in the Damascus Document. Atlanta, GA: Society of Biblical Literature, 2005.

Weber, Max. The Sociology of Religion (4th Revised Edition). Translated by E. Fischoff. Boston: Beacon, 1963 .

Weinfeld, Moshe. Deuteronomy and the Deuteronomic School. Oxford: Clarendon Press, 1972.

Weisberg, Dvora E. "Women and Torah Study in Aggadah." In Women and Judaism:New Insights and Scholarship. Edited by Frederick E. Greenspahn, 41-63. New York: New York University Press, 2009.

Werman, Cana. "Jubilees 3o: Building a Paradigm for the Ban on Intermarriage." Harvard Theological Review 9o(1) (1997): 1-22.

Westbrook, Raymond. Old Babylonian Marriage Law. Horn, Austria: F. Berger, 1988.

- "The Female Slave." In Gender and Law in the Hebrew Bible and the Ancient Near East. Edited by Bernard M. Levinson, Victor H. Matthews, and Tikva FrymerKensky, 214-38. Sheffield: Sheffield Academic Press, 1998.

- "The Prohibition on Restoration of Marriage in Deuteronomy 24:1-4." In Studies in the Bible 1986: Scripta Hierosolymitana 31. Edited by Sara Japhet, 387-405. Jerusalem: Magnes, 1986. 
Westermann, Claus. Genesis 1-11: A Commentary. Translated by John J. Scullion SJ. Minneapolis, MN: Augsburg Fortress, 1984.

- Genesis: An Introduction. Translated by John J. Scullion, SJ. Minneapolis, MN: Augsburg Fortress, 1992.

Wevers, John William. Notes on the Greek Text of Genesis. Atlanta, GA: Scholars Press, 1993.

White Crawford, Sidnie. "Mothers, Sisters, and Elders: Titles for Women in Second Temple Jewish and Early Christian Communities." In The Dead Sea Scrolls as Background to Postbiblical Judaism and Early Christianity. Edited by James Davila, 177-91. Leiden: Brill, 2003.

—. "Not According to Rule: Women, The Dead Sea Scrolls and Qumran." In Emanuel: Studies in Hebrew Bible, Septuagint and Dead Sea Scrolls in Honor of Emanuel Tov. Edited by Shalom M. Paul, Robert A. Kraft, Eva Ben-David, Lawrence H. Schiffman, and Weston W. Fields, 127-50. Leiden: Brill, 2002.

Winslow, Karen S. "Mixed Marriages in Torah Narratives." In Mixed Marriages: Intermarriage and Group Identity in the Second Temple Period. Edited by Christian Frevel, 132-149. New York: T \& T Clark International, 2011.

Yadin, Yigael. Tefilin-shel-rosh. Jerusalem: Ha-ḥevrah le-ḥakirat Erets-yisrael ve-'atikoteha, 1969.

Yinger, J. Milton. Religion, Society and the Individual: An Introduction to the Sociology of Religion. New York: Macmillan, 1957.

Yoreh, Tzemah. "Biblical Criticism Online." Accessed 12 February 2014. http://www .biblecriticism.com

—. "Shekhem and the So-called Rape of Dinah." In Vixens Disturbing Vineyards: Embarrassment and Embracement of Scriptures; Festschrift in Honour of Harry Fox (leBeit Yoreh). Edited by Tzemah Yoreh, Miryam Segal, Aubrey Glazer, and Justin Lewis, 67-78. Boston: Academic Studies Press, 2010.

Zinn, Howard. A People's History of the United States. New York: Harper Perennial, 1980. Zunz, Leopold. Hadrashot Be'Israel and Their Historical Development [Hebrew]. Edited by H. Albeck. Jerusalem: Mossad Bialik, 1954. 